\title{
Benefits of wildlife-based land uses on private lands in Namibia and limitations affecting their development
}

\author{
P. A. Lindeny, C. P. Havemann, R. M. Lines, A. E. Price, T. A. Retief \\ T. Rhebergen, C. VAn DeR WAal and S. S. ROMANaCh
}

\begin{abstract}
Legislative changes during the 1960s-1970s granted user rights over wildlife to landowners in southern Africa, resulting in a shift from livestock farming to wildlifebased land uses. Few comprehensive assessments of such land uses on private land in southern Africa have been conducted and the associated benefits are not always acknowledged by politicians. Nonetheless, wildlife-based land uses are growing in prevalence on private land. In Namibia wildlife-based land use occurs over c. $287,000 \mathrm{~km}^{2}$. Employment is positively related to income from ecotourism and negatively related to income from livestock. While $87 \%$ of meat from livestock is exported $\geq 95 \%$ of venison from wildlife-based land uses remains within the country, contributing to food security. Wildlife populations are increasing with expansion of wildlife-based land uses, and private farms contain 21-33 times more wildlife than in protected areas. Because of the popularity of wildlife-based land uses among younger farmers, increasing tourist arrivals and projected impacts of climate change on livestock production, the economic output of wildlife-based land uses will probably soon exceed that of livestock. However, existing policies favour livestock production and are prejudiced against wildlife-based land uses by prohibiting reintroductions of buffalo Syncerus caffer, a key species for tourism and safari hunting, and through subsidies that artificially inflate the profitability of livestock production. Returns from wildlife-based land uses are also limited by the failure to reintroduce other charismatic species, failure to
\end{abstract}

P.A. LindSEY ${ }^{*}$ (Corresponding author), C.P. HAVEMANN and T.A. ReTIEF Mammal Research Institute, University of Pretoria, Private Bag X20, Hatfield, Pretoria, 0028, South Africa. E-mail palindsey@gmail.com

R.M. LINES Namibia Nature Foundation, Windhoek, Namibia

A.E. PRICE Nebraska Department of Environmental Quality in Lincoln, Nebraska, USA

T. RhEBERgen Department of Plant Production Systems, Wageningen University, The Netherlands

C. VAN DER WAAL Vanderwaal \& Associates Agri-ecological Services, Omaruru, Namibia

S.S. ROMAÑACH African Wildlife Conservation Fund, Doral, USA

${ }^{*}$ Also at: TRAFFIC East/Southern Africa, Harare, Zimbabwe, and Panthera, New York, USA

Received 13 January 2011. Revision requested 6 April 2011

Accepted 26 May 2011. develop fully-integrated conservancies and to integrate black farmers sufficiently.

Keywords Ecotourism, fencing, Namibia, private land, transfrontier, trophy hunting, wildlife

This paper contains supplementary material that can be found online at http://journals.cambridge.org

\section{Introduction}

Wildlife management in southern Africa has evolved through three stages (Child, 2009). With white settlement wildlife populations were decimated by unregulated hunting and habitat fragmentation (MacKenzie, 1988). Declines were exacerbated by outbreaks of bovine pleuropneumonia and rinderpest (Bond et al., 2004). A protectionist phase followed in which colonial administrations established legislation that centralized control over wildlife and limited commercial use, making wildlife on farmlands a burden for landowners (MacKenzie, 1988; Murombedzi, 2003). Wildlife populations continued to wane because of illegal hunting, persecution by landowners, state-sponsored hunting to remove tsetse fly Glossina spp. hosts, and construction of veterinary fences (Child \& Riney, 1987; Taylor \& Martin, 1987; Bond et al., 2004). Negative wildlife population trends improved following legislative changes during the 1960 s and 1970 s that enabled landowners to utilize wildlife on their land (Bond et al., 2004).

During the 1980 s there was a rising demand for tourism and safari hunting, providing incentives for landowners to begin wildlife ranching (Bond et al., 2004). Recurrent droughts, declining range productivity because of overstocking with livestock and declining state subsidies for livestock production hastened the shift to wildlife ranching (Jansen et al., 1992; Child, 2000; Carruthers, 2008). Predictions that wildlife could produce more meat than livestock (Dasmann \& Mossman, 1961) were not borne out because of the costs of harvesting wildlife, veterinary restrictions and lack of support infrastructure. Rather, the comparative advantage of wildlife lay in multiple values from ecotourism, safari hunting, meat and hides (Child, 2000; Carruthers, 2008). Wildlife ranching spread rapidly across semi-arid private lands in southern Africa. There are now at least 9,000 wildlife ranches in South Africa, 
covering c. 205,000 km² (Falkena, 2003; NAMC, 2006). In Zimbabwe there were $27,000 \mathrm{~km}^{2}$ of wildlife ranches prior to so-called land reform (Bond et al., 2004) and in Namibia there were 400 registered hunting farms by 2001 (Krug, 2001).

A growing body of evidence suggests that wildlife-based land uses confer several ecological and socio-economic benefits compared to livestock farming in semi-arid areas (Price-Waterhouse, 1994; Langholz \& Kerley, 2006). For example, wildlife-based land use has resulted in the restoration of degraded rangelands in some areas and stimulated recoveries of wildlife populations, including threatened species (Barnes \& de Jager, 1996; Bothma et al., 2009; Child, 2009). In semi-arid areas wildlife-based land use is commonly more profitable than livestock, generates more foreign currency, and is less susceptible to drought (Price-Waterhouse, 1994; Sims-Castley et al., 2005). Wildlife-based land uses contribute to food security through employment, foreign currency and venison (PriceWaterhouse, 1994; Langholz \& Kerley, 2006).

Few studies have examined the economic, social and conservation impacts of wildlife ranching on private land in southern Africa, despite the scale of the industry. Lack of data and a perception that the primary beneficiaries of wildlife-based land uses are white landowners have meant that wildlife ranching is not always fully supported by governments (Duffy, 2000). Some politicians believe that wildlife ranches threaten food security (du Toit, 2004) and others perceive wildlife ranching as an attempt by white landowners to avoid land reform (Gibson, 1999). Current policies artificially inflate the profitability of livestock farming and suppress that of wildlife ranching through veterinary restrictions on wildlife reintroductions (Scoones \& Wolmer, 2008; Albertson, 2010). Without intervention to raise awareness among politicians of the benefits of wildlifebased land uses there is a risk that land reform will cause a reversion to livestock in areas best suited for wildlife. Southern Africa inherited skewed land ownership from colonial governments and the transfer of land from white to black farmers is a political imperative. There is therefore a need for research into the scale and impacts of wildlife ranching in southern Africa to guide land-use planning, veterinary policies and land reform. Here we provide an assessment of wildlife ranching in Namibia.

\section{Legislative basis for wildlife ranching in Namibia}

Several forms of consumptive utilization of wildlife are allowed on Namibian farmlands with appropriate permits, including: shoot-and-sell (shooting of animals for meat to sell), safari hunting (sale of guided hunts mainly to foreign hunters), management hunts (sale of guided hunts targeting non-trophy animals), biltong hunting (mainly local hunters sold the right to shoot animals for meat), wildlife harvesting (wildlife is culled by specialized teams to produce venison), shooting for own use, and capture and sale of live wildlife (Gödde, 2008). Consumptive wildlife use is governed by the Ministry of Environment and Tourism via Nature Conservation Ordinance No. 4 of 1975. This legislation was amended with the Nature Conservation Amendment Act of 1996, which conferred similar user rights to residents of communal land conservancies (Barnett \& Patterson, 2006). A Parks and Wildlife Management Bill is being drafted but is not yet operational (Laubscher et al., 2007). Permits for consumptive use are allocated by the Ministry of Environment and Tourism following submission of management plans by farmers and field inspections/wildlife counts (Gödde, 2008). Twenty-five conservancies have developed in which multiple landowners manage wildlife cooperatively (comprising 1,008 farms and c. $43,250 \mathrm{~km}^{2}$; Ministry of Environment and Tourism, pers. comm., 2010).

\section{Methods}

A structured, pre-tested questionnaire was used to gather quantitative data on land-use, wildlife, employment and venison production (Appendix). Sixty of the 81 member associations of the Namibian Agricultural Union (NAU) were randomly selected. From each association four farmers were randomly sampled and interviewed in person. If respondents were not reachable, alternatives were randomly selected. Interviews were conducted in English, Afrikaans or Herero by four interviewers. Farmers were informed that the survey was part of a university study on wildlifebased land uses in Namibia and that the results would be anonymous. The interviewers were provided with training in survey techniques and observed multiple pre-tests of the survey and conducted several supervised practice surveys before commencing data collection.

Two hundred and fifty farmers were interviewed (sample distribution is depicted in Fig. 1). Because of multiple farm-ownership/lease-holding the sample covered 412 farms $\left(28,038 \mathrm{~km}^{2}\right)$. There are 3,500 commercial farms in Namibia (Giel Schoombee, NAU, pers. comm., 2010). The margin of error with this sample size is $4.9 \%$ (i.e. $95 \%$ confidence interval). Refusal rate was $4.8 \%$, which is unlikely to introduce non-response bias (Lindner, 2002).

Estimates of wildlife populations and wildlife biomass on freehold farms were made by multiplying mean values per $\mathrm{km}^{2}$ from our sample in each region by the area of farmland in each region. Wildlife biomass was estimated by multiplying the mean mass of individuals of a species ( 0.75 of standard female mass; Hayward et al., 2006) by respondents' estimates of populations of those species on their properties. When estimating venison production mean dressing percentages were multiplied by the number of individuals reported utilized each year (Bothma \& du Toit, 


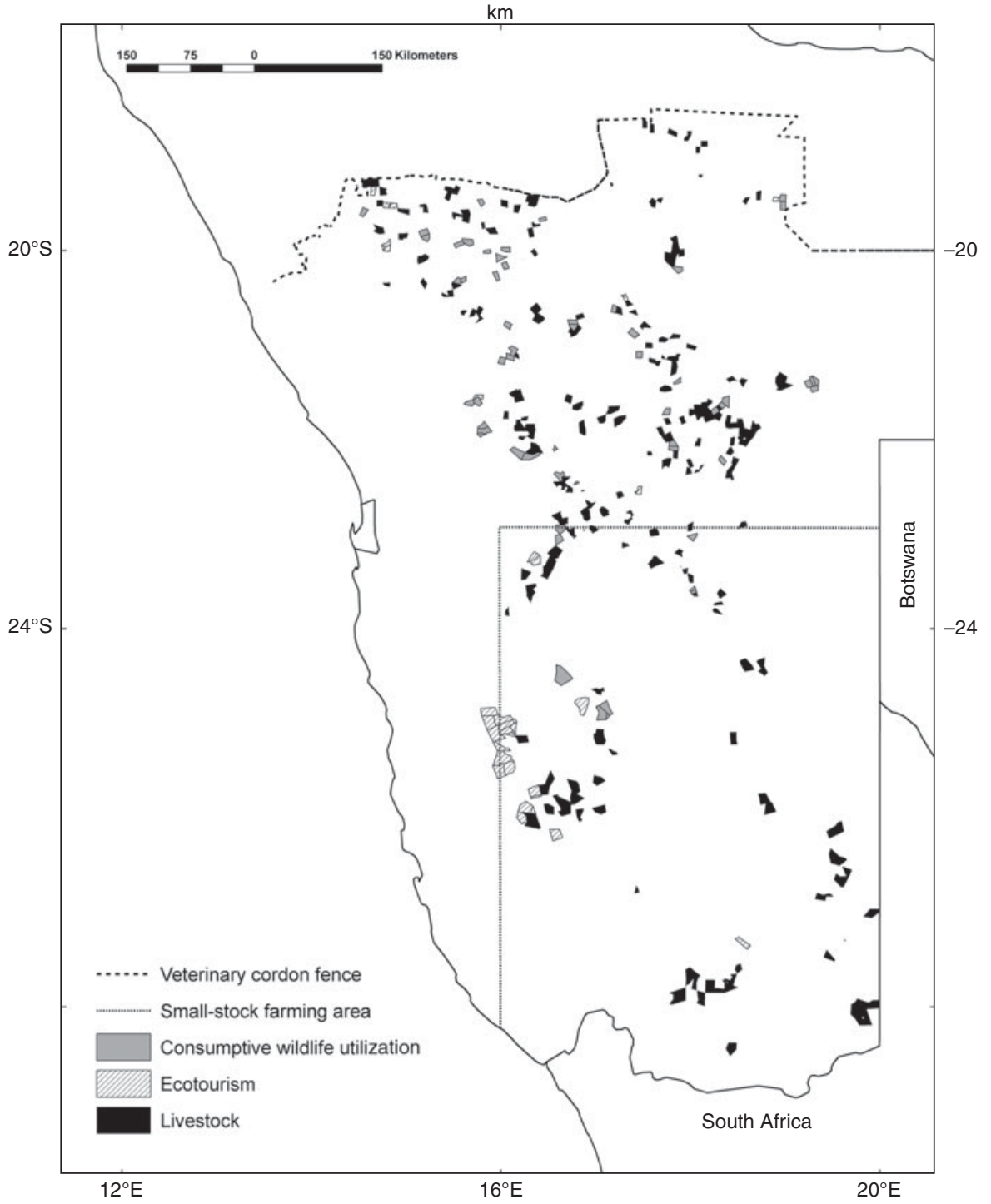

FIG. 1 Spatial patterns in primary land use (i.e. that accounting for the majority of farmers' income) on freehold land in Namibia (categorized as either consumptive wildlife utilization, ecotourism or livestock), and the line denoting the boundary between the small-stock area (to the south) and large-stock area (to the north).
2009). All animals utilized were assumed to be adults (sex ratios of harvests were provided by farmers), except for culling, for which 0.75 of standard female mass was used.

To estimate meat production on a national scale two methods were used. (1) Mean percentage offtake of populations of each species in each region were calculated and multiplied by population estimates for each region (after Barnes et al., 2009). These values were then multiplied by the mean meat yield from an individual of each species via each form of utilization. For small antelopes for which population estimates were not available the percentage of total meat production from the sample that they comprised was calculated, and the national meat production estimate adjusted upwards by the same proportion. (2) Meat production was also calculated based on available land, by multiplying the mean meat production per $\mathrm{km}^{2}$ from all forms of use in each region by the area of farmlands in each region.

Estimates of venison produced per $\mathrm{km}^{2}$ in each region were multiplied by mean prices (from the survey) to calculate earnings from meat. Warthog Phacochoerus africanus meat was assumed not to be sold, except where the species was shot under shoot-and-sell permits, as the sale of meat from the species is restricted (F. Joubert, Directorate of Veterinary Services, pers. comm., 2010).

Survey data were analysed using multiple logistic regressions, $\chi^{2}$ tests and analyses of variance (JMPIN, 2000). When commencing with multiple logistic regressions or analyses of variance all variables expected to influence the dependent variable were included in the models and removed following a backwards stepwise procedure until all remaining variables were statistically significant. To analyse percentage income from different land uses we categorized income data as $0-25 \%$ income, $26-50 \%$ and $>50 \%$.

Data on vegetation, mean annual rainfall, human densities, distances from towns/national roads of each farm in the sample, and estimates of the area of freehold farms in each region were calculated or derived from 
NACSO (2010), using ArcInfo v. 9.3 (ESRI, Redlands, USA). Land was categorized as falling in the 'small-stock' or 'largestock' farming areas, following Erb (2004).

\section{Results}

\section{Interviewees}

Eighty-seven percent $(87.1 \%)$ of respondents interviewed were white, of which $54.2 \%$ were Afrikaans-speaking, $42.1 \%$ were German-speaking and the remainder Englishspeaking. Thirteen percent of farmers were black (of which $74.0 \%$ were Herero and 9.2\% Damara). Of farmers in commercial conservancies, only $0.86 \%$ were black.

\section{Land use}

Livestock production was the most common land use (92.3\% of respondents) and generated the largest mean proportion of respondents' income (66.9\%; Figs 1 \& 2). Cattle were the most widespread livestock (93.4\% of respondents; mean density where kept $5.1 \pm \mathrm{SE} 0.36 \mathrm{~km}^{-2}$ ), followed by sheep $\left(72.7 \%, 13.6 \pm \operatorname{SE} 2.3 \mathrm{~km}^{-2}\right)$, and goats $\left(61.6 \%, 2.20 \pm \mathrm{SE} 0.19 \mathrm{~km}^{-2}\right)$. Percentage income from livestock was influenced by region (highest in Kunene, 79.5\%, and Otjozondjupa, 67.1\%, and lowest in Erongo, 54.2\%) and by age of respondent (higher among older farmers; $\mathrm{F}$ Ratio $=3.69, \mathrm{df}=8, \mathrm{P}<0.001$; JMPIN, 2000).

Seventy-five percent of respondents practised commercial wildlife-based land uses (Fig. 2). Wildlife-based land uses are practised over c. $287,000 \mathrm{~km}^{2}$ and exclusively over c. $32,000 \mathrm{~km}^{2}$ (Table 1). Whether or not wildlife-based land uses are practised was related to conservancy membership (94.0\% of respondents in conservancies cf. $69.4 \%$ outside), and wildlife diversity (9.0 \pm SE 0.32 wild ungulate species where wildlife-based land use is practised cf. 5.2 \pm SE 0.26). Percentage of income from wildlife-based land uses was higher among conservancy members $(35.3 \%$ cf. $19.1 \%$ among non-members) and was higher among whites than blacks (29.6\% cf. 6.6\%).

The commonest forms of wildlife-based land uses were shoot-and-sell, safari hunting and ecotourism (Fig. 2). Safari hunting (9.2\%), ecotourism (6.8\%) shoot-and-sell (2.7\%), live sales $(1.8 \%)$ and biltong hunting $(1.3 \%)$ generated most income from wildlife-based land uses (Table 1). Percentage of income from safari hunting was greater among younger ranchers and among conservancy members $(22.6 \%$ cf. $7.5 \%$; $\mathrm{F}$ Ratio $=11.5, \mathrm{df}=2, \mathrm{P}<0.001)$. Percentage income from ecotourism was higher in the small-stock than large-stock area $(7.7 \%$ cf. $6.4 \%)$.

Twenty-one percent $(21.4 \%)$ of farmers would consider removing all livestock and practising only wildlife-based land uses in the future. Willingness of respondents to make

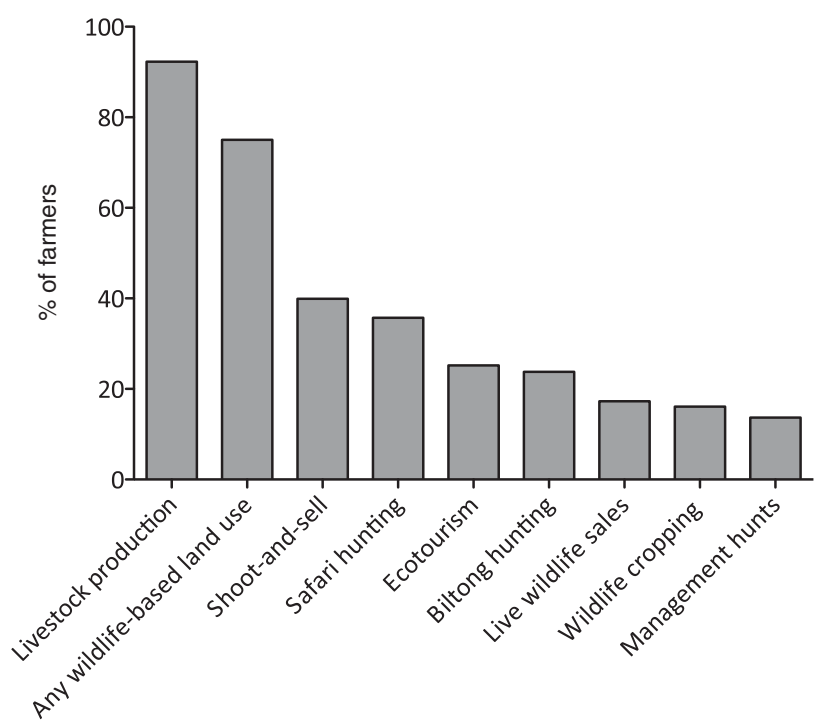

FIG. 2 Percentage of farmers interviewed who were engaged in various land-use forms (wildlife cropping refers to the large-scale culling of wildlife to produce meat for sale, the shooting often done at night, and differs from shoot-and-sell which typically involves the more selected removal of one individual at a time).

such a change was influenced by race (30.8\% of blacks were willing cf. $20 \%$ of whites), proportion of income from ecotourism (willing respondents derived $8 \%$ of income from ecotourism cf. $4 \%$ among unwilling respondents), proportion of income from safari hunting (willing respondents derived $22 \%$ of income from safari hunting cf. $11 \%$ among unwilling respondents), and respondents' distance from a town (willing respondents were nearer towns $142 \pm$ SE $20 \mathrm{~km}$ cf. $192 \pm$ SE $\left.11.4 \mathrm{~km} ; \chi^{2}=152, \mathrm{df}=158, \mathrm{P}<0.001\right)$. Most farms have stock-proof fencing, even in conservancies (Table 2). Game-proof fencing is relatively uncommon (Table 2).

\section{Wildlife populations}

Wildlife populations on freehold land may be larger than previously recognized (Barnes et al., 2009; Table 3). Wild ungulate diversity was higher in conservancies (10.1 \pm SE 0.39 species per farm cf. $6.72 \pm \mathrm{SE} 0.36$ ), positively related to income from safari hunting (ranchers obtaining with $0-25 \%$ of their income from safari hunting had $5.4 \pm$ SE 0.2 species, those earning $26-50 \%$ had $10.8 \pm$ SE 4.4 species, and those deriving $>50 \%$ had $12.4 \pm$ SE 0.8 species), negatively related to income from livestock (ranchers obtaining $0-25 \%$ of income from livestock had 10.3 \pm SE 1.2 species, those earning $26-50 \%$ had $10.8 \pm \mathrm{SE} 0.65$ species, and those deriving $>50 \%$ had $7.0 \pm$ SE 0.3 species), negatively related to farmer age, and influenced by vegetation ( $\mathrm{F}$ Ratio $=18.9, \mathrm{df}=15$, $\mathrm{P}<0.001$ ). Wildlife diversity was highest in thorn-bush shrub-land (11.6 \pm SE 0.9 species) and southern Kalahari (10.3 \pm SE 1.3), and lowest in Karas dwarf shrub-land 


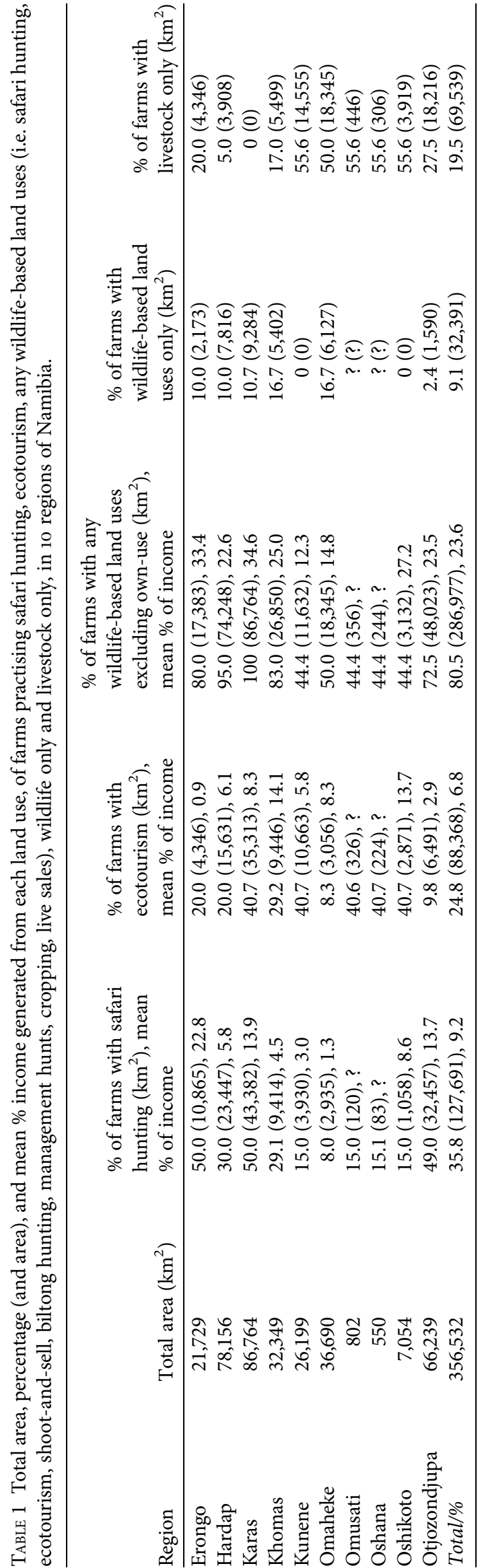

(4.4 \pm SE 0.5). Four of the so-called big five (buffalo Syncerus caffer, lion Panthera leo, elephant Loxodonta africana and rhinoceros Diceros bicornis) were rare on farms whereas the leopard Panthera pardus was not (Fig. 3). Springbok Antidorcas marsupialis, oryx Oryx gazella, kudu Tragelaphus strepsiceros and warthog were the most abundant species on farmlands (Table 3 ).

Livestock biomass (mean 2,251 \pm SE $140 \mathrm{~kg} \mathrm{~km}^{-2}$ ) was higher than wild ungulate (and ostrich Struthio camelus) biomass (936 $\pm \mathrm{SE} 84.1 \mathrm{~kg} \mathrm{~km}^{-2}$; F Ratio $=64.0, \mathrm{df}=1$, $\mathrm{P}<0.001)$. Livestock production on freehold land contributed NAD 1.97 billion (USD 235 million at mean 2009 rates) to gross national income (GNI) in 2009, compared to at least USD 166 million from wildlife and tourism (Barnes et al., 2010). Wildlife biomass is thus more efficient at generating revenue than livestock. Wildlife, which comprises $29.4 \%$ of mammalian biomass, generates $41.5 \%$ of the revenue from livestock, wildlife and tourism combined, or $1.41 \%$ revenue per $1 \%$ biomass, whereas livestock generates $0.83 \%$ revenue per $1 \%$ biomass.

Wildlife biomass was negatively related to income from livestock (ranchers earning $0-25 \%$ of income from livestock had $2,712 \pm$ SE $900 \mathrm{~kg}$ of wildlife biomass $\mathrm{km}^{-2}$, those deriving $26-50 \%$ had $1,516 \pm$ SE $137 \mathrm{~kg} \mathrm{~km}^{-2}$, and those deriving $>50 \%$ had $911 \pm$ SE $136 \mathrm{~kg} \mathrm{~km}^{-2}$ ), positively related to income from safari hunting (ranchers deriving 0-25\% of income from safari hunting had $973 \pm$ SE $256 \mathrm{~kg}$ of wildlife biomass $\mathrm{km}^{-2}$, those deriving $26-50 \%$ had 1,369 \pm SE $108 \mathrm{~kg}$ $\mathrm{km}^{-2}$, and those deriving $>50 \% 2,179 \pm 258 \mathrm{~kg} \mathrm{~km}^{-2}$ ), and positively related to income from ecotourism (ranchers deriving $0-25 \%$ from ecotourism had $1,129 \pm 123 \mathrm{~kg}$ of wildlife biomass $\mathrm{km}^{-2}$, those deriving $26-50 \%$ had $1,137 \pm \mathrm{SE}$ $166 \mathrm{~kg} \mathrm{~km}^{-2}$, and those deriving $>50 \%$ had 2,849 $\pm 1,324 \mathrm{~kg}$ $\mathrm{km}^{-2}$ ), and was positively related to wildlife diversity ( $\mathrm{F}$ Ratio $=69.9, \mathrm{df}=8, \mathrm{P}<0.001$ ). Some ranchers have significant wildlife populations and yet generate little or no income from wildlife-based land uses, suggesting that the resource is underutilized in some areas.

Fifty-eight percent $(57.6 \%)$ of respondents thought wildlife populations were increasing on their land, $23.7 \%$ thought they were stable, and $18.6 \%$ thought they were declining. Percentage of income from safari hunting was higher on properties with stable or increasing wildlife populations $(18.7 \pm \mathrm{SE} 2.8 \%)$ than where wildlife was declining $\left(1.50 \pm\right.$ SE $\left.0.76 \% ; \chi^{2}=12.1, \mathrm{df}=4, \mathrm{P}<0.001\right)$. Wildlife was more commonly stable or increasing inside $(87.9 \%)$ than outside conservancies $\left(75.0 \% ; \chi^{2}=3.3, \mathrm{df}=1, \mathrm{P}=0.068\right)$. Explanations for increasing wildlife populations included favourable rainfall (35.3\%; rainfall was generally above average during 2000-2009; Namibian Ministry of Works and Transport, 2011), good management (26.4\%), conservative harvests (19.1\%, Table 4), artificial water-points (10.3\%), and incentives for conservation through safari hunting (8.8\%). Explanations for declining wildlife populations 
TABLE 2 Percentage occurrence of various forms of fencing on Namibian commercial farmlands.

\begin{tabular}{|c|c|c|c|c|c|c|}
\hline & $\begin{array}{l}\text { No } \\
\text { fence }\end{array}$ & $\begin{array}{l}\text { Stock } \\
\text { proof }\end{array}$ & $\begin{array}{l}\text { Jackal } \\
\text { proof }\end{array}$ & $\begin{array}{l}\text { Partial } \\
\text { game } \\
\text { proof }\end{array}$ & $\begin{array}{l}\text { Jumping } \\
\text { game } \\
\text { proof }\end{array}$ & $\begin{array}{l}\text { Non- } \\
\text { jumping } \\
\text { game proof }\end{array}$ \\
\hline Overall area & 1.2 & 88.7 & 28.0 & 10.7 & 26.8 & 5.4 \\
\hline Small stock & 0 & 93.3 & 84.4 & 0 & 22.2 & 0 \\
\hline Large stock & 1.6 & 86.9 & 7.3 & 14.6 & 21.1 & 7.3 \\
\hline \multicolumn{7}{|c|}{ In conservancy? } \\
\hline Yes & 2.6 & 76.7 & 3.4 & 6.0 & 38.8 & 6.0 \\
\hline No & 0 & 91.0 & 32.8 & 24.1 & 22.3 & 6.0 \\
\hline
\end{tabular}

among the $18.6 \%$ of ranches reporting such trends included excessive utilization (50.0\%), drought (13.6\%), poaching (9.1\%), and persecution by livestock farmers (4.5\%).

\section{Meat production}

An annual mean of $67.7 \pm \mathrm{SE} 6.8 \mathrm{~kg}$ of venison was produced per $\mathrm{km}^{2}$ on farmland. Safari hunting generated the highest quantity of venison (21.9 \pm SE $\left.3.9 \mathrm{~kg} \mathrm{~km}^{-2}\right)$, followed by shooting for own use $\left(21.1 \pm \mathrm{SE} 3.0 \mathrm{~kg} \mathrm{~km}^{-2}\right)$, shoot-and-sell (13.9 \pm SE $\left.2.6 \mathrm{~kg} \mathrm{~km}^{-2}\right)$ and biltong hunting (6.5 $\left.\pm \mathrm{SE} 1.5 \mathrm{~kg} \mathrm{~km}^{-2}\right)$. Most venison was from oryx, kudu and springbok (Table 4). Typical harvests of wildlife on Namibian farms were well within intrinsic rates of increase for those species (Table 4). Venison production per $\mathrm{km}^{2}$ was related positively to wildlife biomass, wildlife diversity and livestock biomass ( $\mathrm{F}$ Ratio $=48.9, \mathrm{df}=3, \mathrm{P}<0.001$ ).

Between 15,917 $\mathrm{t}$ (extrapolated from mean utilization of available wildlife populations) and 24,952 t (extrapolated from mean production per $\mathrm{km}^{2}$ to available land area) of venison are produced on freehold farms per year (Tables 4 \& 5). In contrast, 93,045 t of meat from domestic stock are produced in Namibia (including communal land) annually, of which $86.9 \%$ is exported (W. Schutz, Namibian Meat Board, pers. comm., 2010). Approximately $805 \mathrm{t}$ of venison are exported from Namibia each year (including $85 \mathrm{t}$ to Europe, 160 t exported legally to South Africa, and a tentative estimate of 720 t smuggled to South Africa; Laubscher, 2007; D. Museler, pers. comm., 2010). These exports correspond to $3.0-5.0 \%$ of venison produced on freehold land, so more venison than meat from livestock on freehold land remains in Namibia (15,200-22,200 t cf. 12,100 t).

Venison is typically sold to butcheries (37.0\%), used for workers' rations $(23.5 \%)$, or personal consumption (13.7\%). Sixty-five percent $(64.6 \%)$ is sold as whole carcasses, $22.5 \%$ as unselected cuts, $6.8 \%$ as processed meat and $5.4 \%$ as selected cuts. Prices obtained by farmers for unprocessed venison increased from c. USD $1.42 \mathrm{~kg}^{-1}$ in 2006/2007, to USD $2.07 \mathrm{~kg}^{-1}$ in 2009 but remains lower than the beef (USD 2.44) and sheep price (USD 2.50; mean 2009 Namibian Meat Board values). Prices of meat from eland
Tragelaphus oryx and springbok were 14.1 and 9.8\% higher than other wildlife species. Farmers obtained higher prices for selected cuts (USD $3.71 \mathrm{~kg}^{-1}$ ) and processed venison (USD $9.47 \mathrm{~kg}^{-1}$ ).

Annual earnings from venison sales were USD 12.4$116.0 \mathrm{~km}^{2}$ depending on the region; extrapolating from this USD 23.8 million was generated annually from meat sales on freehold land. Including meat obtained from harvesting/culling and shoot-and-sell from eland, hartebeest Alcelaphus buselaphus, impala, oryx, kudu, springbok and Hartmann's mountain zebra Equus zebra (species likely to be most marketable) c. 4,10o $t$ of venison could be exported annually from farmland, which could generate a potential annual return of USD 34.6 million, assuming a price of USD $9.47 \mathrm{~kg}^{-1}$ and that a market exists for that quantity of venison.

Farm workers receive more venison as rations $(3.82 \pm \mathrm{SE}$ $\left.0.34 \mathrm{~kg} \mathrm{week}^{-1}\right)$ than meat from livestock $(2.11 \pm \mathrm{SE} 0.42 \mathrm{~kg}$ week $^{-1} ; \quad \mathrm{F}$ Ratio $\left.=8.1, \quad \mathrm{df}=1, \quad \mathrm{P}=0.005\right)$. There are c. 22,855 workers on commercial farmland in Namibia (Giel Schoombee, pers. comm., 2010) and, extrapolating from our sample, c. 4,500 t of meat are used to feed workers annually compared to c. 2,50o $t$ of meat from livestock. Venison rations probably benefit $>33$,000 workers and their dependants on freehold farms.

\section{Employment}

Respondents employed 9.91 \pm SE 0.94 workers per management unit (farm or multiple adjacent farms managed by one person or company), or $0.22 \pm \mathrm{SE} 0.08$ workers $\mathrm{km}^{-2}$. Farmers housed an additional 1.94 \pm SE 0.11 family members per worker, or a total of $26.4 \pm$ SE 1.9 people per management unit ( $0.41 \pm \mathrm{SE} 0.09$ people $\mathrm{km}^{-2}$ ). Employment was positively related to income from ecotourism (farmers earning $0-25 \%$ of income from ecotourism employed $0.10 \pm$ SE 0.01 people $\mathrm{km}^{-2}$, those deriving $25-50 \%$ employed $0.09 \pm$ SE $0.01 \mathrm{~km}^{-2}$ and those deriving $>50 \%$ employed $0.31 \pm$ SE $0.09 \mathrm{~km}^{-2}$ ), and negatively related to income from livestock (farmers deriving $0-25 \%$ of income from livestock employed $0.24 \pm$ SE 0.03 people $\mathrm{km}^{-2}$, those 
TABLE 3 Estimates of wildlife populations on freehold land, by region and overall, based on mean densities of each species derived from farmers' estimates of population sizes, and the estimates of Barnes et al. (2009), ordered by total population.

\begin{tabular}{|c|c|c|c|c|c|c|c|c|c|c|}
\hline & Erongo & Hardap & Karas & Khomas & Kunene & Omaheke & Otjozondjupa & $\begin{array}{l}\text { Oshikoto/ } \\
\text { Oshana/ } \\
\text { Omusati }^{1}\end{array}$ & Total $^{2}$ & $\begin{array}{l}\text { Barnes } \\
\text { et al. (2009) }\end{array}$ \\
\hline Springbok Antidorcas marsupialis & 38,243 & 332,946 & 239,470 & 71,491 & 14,409 & 25,683 & 35,769 & 4,623 & 762,634 & 621,561 \\
\hline Oryx Oryx gazella & 66,057 & 111,764 & 32,970 & 83,460 & 36,155 & 41,093 & 119,230 & 11,599 & 502,328 & 350,092 \\
\hline Kudu Tragelaphus strepsiceros & 52,150 & 60,962 & 29,500 & 52,082 & 54,756 & 41,093 & 141,089 & 17,567 & 449,199 & 345,801 \\
\hline Warthog Phacochoerus africanus & 52,585 & 37,515 & 2,603 & 78,931 & 30,129 & 72,279 & 139,765 & 9,666 & 423,473 & 174,115 \\
\hline Hartebeest Alcelaphus buselaphus & 8,474 & 35,170 & 3,471 & 54,023 & 5,764 & 39,258 & 38,419 & 1,849 & 186,428 & 122,805 \\
\hline Eland Tragelaphus oryx & 4,129 & 2,345 & 781 & 7,117 & 8,646 & 7,705 & 56,303 & 2,774 & 89,800 & 37,216 \\
\hline Hartmann's zebra Equus zebra & 11,299 & 22,665 & 868 & 17,468 & 9,956 & 1,834 & 13,910 & 3,194 & 81,194 & 55,520 \\
\hline Blue wildebeest Connochaetes taurinus & 1,304 & 17,976 & 1,041 & 11,646 & 5,764 & 6,971 & 29,145 & 1,849 & 75,696 & 16,623 \\
\hline Ostrich Struthio camelus & 1,521 & 15,631 & 11,366 & 8,087 & 4,391 & 7,705 & 19,209 & 1,409 & 69,319 & 36,336 \\
\hline Common impala Aepyceros melampus & 3,107 & 7,034 & 0 & 8,411 & 2,358 & 6,971 & 33,120 & 756 & 61,757 & 15,442 \\
\hline Black wildebeest Connochaetes gnu & 1,956 & 6,253 & 781 & 10,675 & 1,834 & 8,439 & 15,434 & 588 & 45,959 & ? \\
\hline Waterbuck Kobus ellipsiprymnus & 43 & 1,563 & 347 & 4,205 & 1,310 & 8,806 & 12,254 & 420 & 28,949 & 4,475 \\
\hline Giraffe Giraffa camelopardalis & 2,162 & 977 & 71 & 981 & 3,151 & 5,635 & 9,731 & 1,011 & 23,719 & 5,769 \\
\hline Plains zebra Equus quagga & 435 & 3,908 & 0 & 4,432 & 576 & 2,201 & 7,949 & 185 & 19,686 & 25,421 \\
\hline Black-faced impala Aepyceros melampus petersi & 326 & 1,563 & 434 & 0 & 2,201 & 972 & 7,286 & 706 & 13,488 & 3,370 \\
\hline Sable Hippotragus niger & 0 & 0 & 0 & 0 & 157 & 73 & 1,987 & 50 & 2,268 & 1,233 \\
\hline Lechwe Kobus leche & 0 & 0 & 0 & 0 & 79 & 0 & 795 & 25 & 899 & 1,188 \\
\hline Tsessebe Damaliscus lunatus & 0 & 0 & 0 & 0 & 629 & 0 & 66 & 202 & 897 & 162 \\
\hline Roan Hippotragus equinus & 0 & 0 & 0 & 0 & 0 & 0 & 331 & 0 & 331 & 1,090 \\
\hline Total & 243,791 & 658,272 & 323,703 & 413,009 & 182,265 & 276,718 & 681,792 & 58,473 & $2,838,023$ & $1,818,219$ \\
\hline
\end{tabular}

${ }^{1}$ Assuming that wildlife densities in Oshikoto, Oshana and Omusati equal those in Kunene, the nearest region for which density estimates are available

${ }^{2}$ Assuming an area of $356,533 \mathrm{~km}^{2}$ of freehold land (Mendelsohn, 2006) 


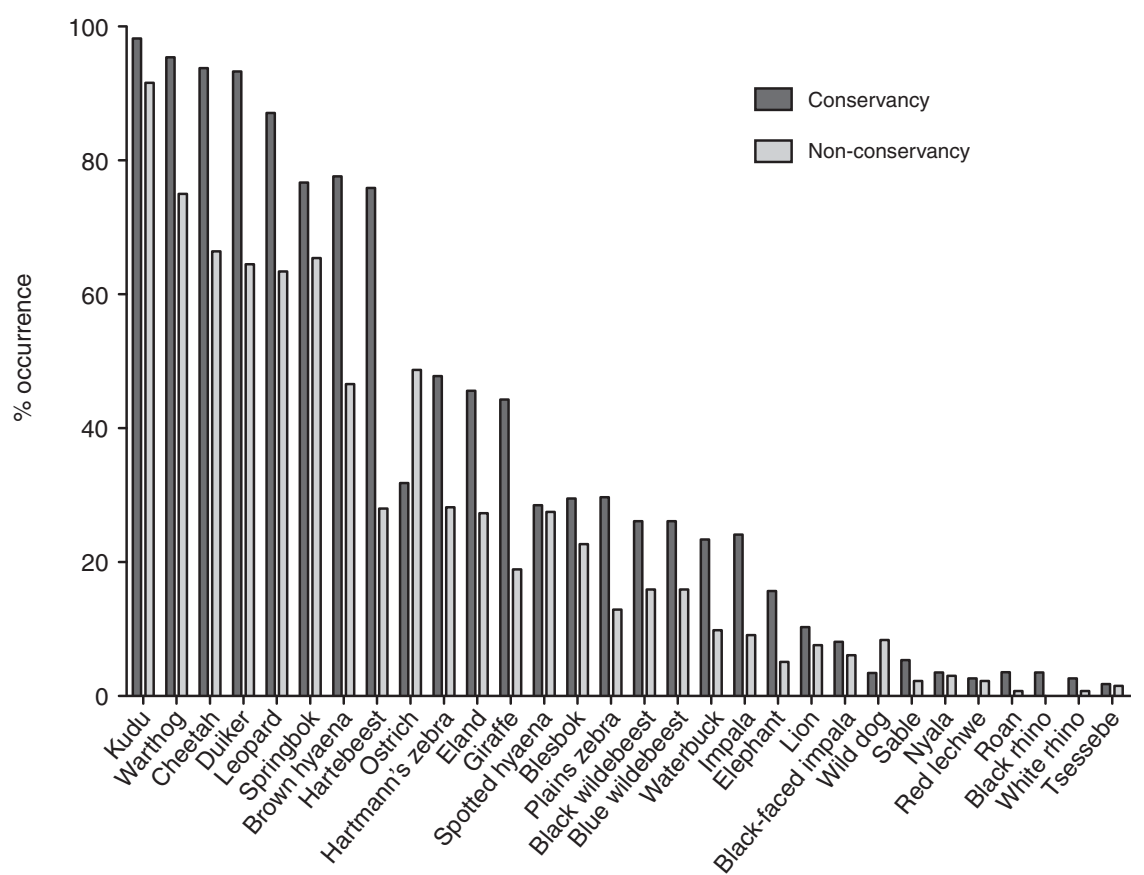

FIG. 3 Percentage occurrence of large wild mammals on Namibian farmlands within and outside of conservancies. deriving $25-50 \%$ employed $0.14 \pm$ SE $0.02 \mathrm{~km}^{-2}$ and those deriving $>50 \%$ employed $0.08 \pm \mathrm{SE} \quad 0.01 \quad \mathrm{~km}^{-2} ; \mathrm{F}$ Ratio $=12.3, \mathrm{df}=3, \mathrm{P}<0.001)$.

\section{Discussion}

The veracity of our findings is dependent on the reliability of the answers provided by respondents. Because of the care taken when explaining the purpose of the study to respondents, linguistic matching of respondents and interviewers, and the anonymous and non-contentious nature of the survey, respondents were willing to participate and we believe the data provided are reliable. Wildlife-based land use is practised by $75 \%$ of Namibian farmers (according to our data), and is increasing in prevalence (Barnes \& Jones, 2009). Safari hunting is a more commonly practised form of wildlife-based land use on freehold land than ecotourism (and generates a higher mean percentage of farmers' earnings), contrasting with the findings of Barnes et al. (2009). Our study may have underestimated the contribution of ecotourism: farms practising large-scale ecotourism can generate high revenues but are probably clustered spatially and may be underrepresented in our survey (J. Barnes, pers. comm., 2010).

Livestock farming is the most widespread land-use and generates the majority of income for most farmers. However, livestock numbers have declined on freehold land in recent years because of range degradation (including bush encroachment) caused by overgrazing and the rise of wildlife-based land uses (de Klerk, 2004; Barnes \& Jones, 2009), although improved herd management has maintained output (Erb, 2004). Wildlife production is probably less affected by bush encroachment (many species are browsers) and, as long as stocking rates are not excessive, replacement of livestock with wildlife should stimulate gradual rangeland recovery (Child, 2009).

\section{Economic role of wildlife-based land uses}

Wildlife and tourism on freehold land contributed USD 166 million to GNI in Namibia in 2009 (or USD 213 million, if all natural resources are taken into account), compared to USD 235 million from livestock (Barnes et al., 2010). These estimates are conservative, as the economic value of venison (USD 23.8 million per year, excluding export earnings) is higher than previously thought (USD 532,544; Barnes et al., 2009). The economic contribution of wildlife and tourism on freehold land may already exceed that of livestock despite policies and subsidies favouring the latter. With continued growth in tourist and hunter arrivals likely, the economic contribution of wildlife will probably increase further. The trophy hunting industry increased in value from USD 28.5 to 44.8 million during 2004-2007 (Lamprechts, 2009) and international tourist arrivals in Namibia are predicted to increase by $5.7 \%$ per annum over the next 10 years (WTTC, 2012). Wildlife-based land uses are popular among younger farmers and earnings from wildlife are projected to be $60 \%$ less affected by climate change than those from livestock (Barnes et al., 2010).

\section{Social benefits of wildlife-based land uses}

Employment on Namibian farmlands is related positively to income from ecotourism but negatively to income from 
TABLE 4 Game meat production on Namibian freehold farms, the percentage of meat produced in each region, offtake as a proportion of populations and intrinsic rates of increase for each species by comparison, ordered by estimate of meat produced.

\begin{tabular}{|c|c|c|c|c|}
\hline & $\begin{array}{l}\text { Conservative estimate } \\
\text { of meat produced }(\mathrm{kg})^{1}\end{array}$ & $\%$ of meat & $\begin{array}{l}\text { Offtake as a } \% \\
\text { of populations }^{2}\end{array}$ & $\begin{array}{l}\text { Intrinsic rates } \\
\text { of increase }\end{array}$ \\
\hline Oryx & $5,993,803$ & 37.7 & 14.3 & 21.9 \\
\hline Kudu & $3,477,249$ & 21.8 & 9 & 24.4 \\
\hline Springbok & $2,210,013$ & 13.9 & 17.9 & 40.9 \\
\hline Eland & $1,066,053$ & 6.7 & 9.9 & 16.5 \\
\hline Hartebeest & 842,772 & 5.3 & 9.4 & 26.8 \\
\hline Hartmann's zebra & 718,593 & 4.5 & 8.2 & 19.8 \\
\hline Warthog & 559,702 & 3.5 & 8.3 & 34.4 \\
\hline Blue wildebeest & 350,133 & 2.2 & 17.1 & 23.1 \\
\hline Other species ${ }^{3}$ & 207,260 & 1.3 & & \\
\hline Giraffe & 159,051 & 1.0 & 4.3 & 13.3 \\
\hline Plains zebra & 141,386 & 0.9 & 10.6 & 18.8 \\
\hline Common impala & 116,310 & 0.7 & 22.5 & 38.1 \\
\hline Waterbuck & 63,993 & 0.4 & 9.7 & 23.1 \\
\hline Sable antelope & 9,029 & 0.1 & 7.6 & 21.9 \\
\hline Black-faced impala & 1,367 & 0.0 & 2 & 38.1 \\
\hline Total & $15,916,714$ & 100 & & \\
\hline
\end{tabular}

${ }^{1}$ Extrapolating from population estimates made by Barnes et al. (2009); this is conservative as our estimates of wildlife populations are considerably higher ${ }^{2}$ Calculated as the total number of animals of each species harvested on the ranches surveyed as a percentage of the populations of those species estimated by the ranchers

${ }^{3}$ Black wildebeest, nyala Tragelaphus angasi, tsessebe, white rhinoceros Ceratotherium simum, klipspringer Oreotragus oreotragus, dik dik, grey duiker Sylvicapra grimmia, blesbok Damaliscus pygargus, ostrich

livestock, in keeping with findings from Zimbabwe (PriceWaterhouse, 1994) and South Africa (Langholz \& Kerley, 2006). In the Eastern Cape the switch to wildlife-based land uses increased employment by 4.5 times, wage bills by 32 times and conferred improved working conditions for employees (Langholz \& Kerley, 2006). Such improvements are crucial as farm workers earn among the lowest wages (LEAD, 2005). Wildlife-based land uses also confer social benefits through protein provision. More venison is produced on Namibian farms than previously recognized (16,000-23,000 cf. 4,300 t, Laubscher et al., 2007) and acts as a key food source for workers and their families.

\section{Ecological significance of wildlife-based land uses}

The area of farmland used for wildlife-based land uses is more than twice as large as the protected area network (c. 287,000 cf. $114,079 \mathrm{~km}^{2}$, Cumming, 2004). Although the primary objective of wildlife ranches is typically profit they nonetheless confer biodiversity gains. For example, 82,000 Hartmann's mountain zebras and 13,500 black-faced impalas Aepyceros melampus petersi live on Namibian farmlands, and cheetahs Acinonyx jubatus are present on $71.2 \%$ of farms (our data). Populations of most wildlife species are increasing on farmlands and the proportion of mammalian biomass comprised by wildlife increased from $8 \%$ in 1972 to $29 \%$ in 2009 (Barnes \& de Jager, 1996). Wildlife numbers on commercial farms (1.8-2.8 million) exceed those in protected areas (c. 121,000) and community conservancies (150,000-200,000; Barnes et al., 2009; C. Weaver,
WWF-Namibia, pers. comm.). Wildlife abundance on freehold land may also be higher than previous estimates. Our extrapolations of wildlife numbers require caution as they rely on farmers' estimates. However, the Ministry of Environment and Tourism (and conservancies) conduct regular wildlife counts and most farmers probably have a reasonable impression of their wildlife populations.

There are, however, a number of conservation problems on Namibian farmlands, including continued intolerance towards predators (Marker et al., 2003). Lions and wild dogs Lycaon pictus occur on $<10 \%$ of farms, suggesting that lethal control is preventing them from recovering. Ranchers may persecute predators to protect their investment in valuable extralimital wildlife species. In addition, the increasing prevalence of game-proof fencing can interrupt natural processes such as migration, reduce the ability of ungulates to utilize patchy primary productivity (Fryxell \& Sinclair, 1988) and increase the risk of localized overstocking (Lindsey et al., 2009). Finally, although wild ungulate populations are thriving in most areas, there are negative trends in some groups of farms. Such trends are possibly because of excessive harvesting related to high venison prices and are most common outside conservancies, where harvests are not coordinated.

\section{Lack of development of wildlife ranching in Namibia}

Despite expansion of wildlife-based land uses in Namibia it has not yet been embraced as fully by farmers as in South Africa or, as formerly, in Zimbabwe. Most Namibian 


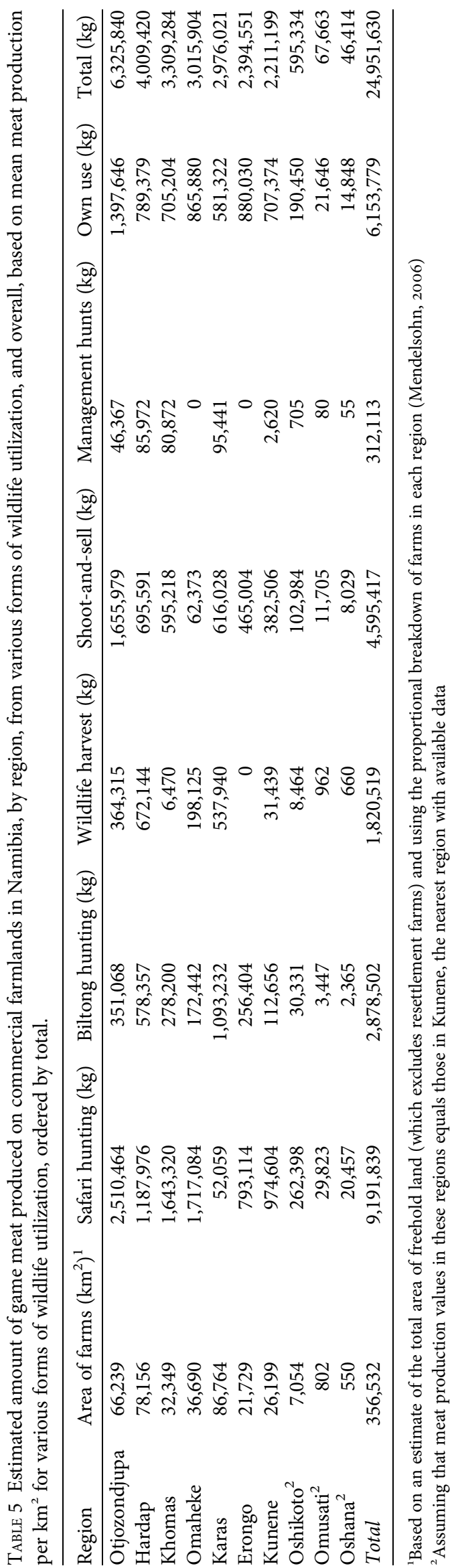

farmers $(>90 \%)$ retain livestock whereas by $2001>50 \%$ of ranchers in several semi-arid parts of South Africa and Zimbabwe had removed all livestock (Lindsey et al., 2009). Six factors in particular undermine the development and value of wildlife-based land uses in Namibia.

Inadequate devolution of user rights over wildlife In Namibia user-rights over wildlife were not devolved as far to landowners as in Zimbabwe and South Africa (NNF, 2010). Landowners in Namibia are required to apply for permits to hunt wildlife, reducing management flexibility and profitability, increasing transaction time and costs, and impinging on farmers' autonomy, thus creating disincentives for wildlife-based land uses (NNF, 2010). The permit system and seasonal restrictions on hunting also limit venison exports (Gödde, 2008).

Veterinary restrictions A veterinary cordon across northern Namibia controls the spread of foot-and-mouth disease to retain access to export markets for beef. Most freehold farms occur south of the cordon in the foot-and-mouth disease free zone, where the reintroduction of buffalo is prohibited (including individuals free of foot-and-mouth disease; DVS, 2007). The buffalo is a key species for safari hunting because it commands high trophy fees (USD 6,400 cf. $<$ USD 1,000 for most antelopes) and is used to sell hunting packages (buffaloes generate c. USD 14,000 in daily rates per hunt cf. c. USD 4,00o for antelope hunts; P. Lindsey, unpubl. data). Buffaloes generate $4.1-49.0 \%$ of income from safari hunting depending on the country (Lindsey et al., 2012). Historically, the buffalo occurred in most areas with $>250 \mathrm{~mm}$ of rainfall, including much of what is now farmlands (Martin, 2004). Costs of veterinary restrictions are borne by the state but the benefits are enjoyed by individual farmers, artificially inflating the profitability of livestock (Scoones \& Wolmer, 2008). Nonetheless, the profitability of commercial livestock production is low across much of southern Africa (Jansen et al., 1992; McLaughlin, 2010) and is projected to decline (Barnes et al., 2009). Long-term access to European markets for beef is not guaranteed, the costs of maintaining veterinary restrictions are increasing and the efficacy of control measures for foot-and-mouth disease is declining (Scoones \& Wolmer, 2008; Thomson, 2008). The wisdom of continued subsidization of the livestock industry at the expense of wildlife-based land uses is thus questionable. At the very least provision should be made for the reintroduction of certified disease-free buffalo on wildlife ranches in the freehold farming area. Alternatively, several different approaches to veterinary control could be considered to allow for the unfettered development of wildlife-based land uses in certain areas. For example, footand-mouth disease-infected zones could be expanded, or veterinary disease control could be compartmentalized, to allow for the creation of wildlife production zones in areas of particularly suitable habitat. Lastly, commodity-based trade 
could be considered (Scoones \& Wolmer, 2008). Through commodity-based trading meat processed in a manner proven to provide minimal risk of transmitting foot-andmouth disease would be acceptable for export (Thomson, 2008). If accepted by the International Organization for Animal Health and the EU, commodity-based trading would provide scope for reintroduction of buffalo on freehold land while permitting continued export of beef (Cumming, 2010).

Failure to reintroduce other high-value species Because of the shortage of so-called big game on freehold land most farmers offer similar, low-value hunting/tourism products involving antelopes. In South Africa ranchers with the big five charge more than double for ecotourism than individuals lacking these species (Lindsey et al., 2009). Namibia and Botswana generate similar revenues from safari hunting even though Namibia attracts 4,000-6,000 annually compared to the 500 that visit Botswana (Martin, 2008; NAPHA, pers. comm.), because of the shortage of high-value species on Namibian farms (Humavindu \& Barnes, 2003).

Failure to develop fully integrated conservancies A key reason for the absence of the largest species on farmlands is the failure of landowners to cooperate to form fully integrated conservancies. In Zimbabwe and South Africa large conservancies have developed in which all livestock and internal fencing has been removed, and all indigenous mammal species reintroduced (Lindsey et al., 2009). By contrast, Namibian conservancies lack key species, are fractured because not all farms within their boundaries are members, and typically retain livestock and internal fencing. Fully integrated conservancies would facilitate higher-end ecotourism and safari hunting and would confer a variety of social and ecological benefits (Lindsey et al., 2009). At present, however, the Namibian government does not formally recognize private conservancies and the permit system discourages their formation. Landowners with properties surrounded by game fencing are granted longer hunting seasons and more complete user rights over wildlife than those without fencing (including within conservancies; Gödde, 2008). This situation should be reversed.

Failure to integrate development of wildlife-based land uses with land reform As currently practised in Namibia land reform may cause a shift from wildlife-based land uses to livestock because of a lack of the necessary experience, expertise and start-up capital among many emerging farmers, and inadequate efforts by government to promote their integration into wildlife ranching. Government could identify suitable farms as wildlife ranches and purchase them for allocation to interested emerging farmers, whom our data suggest may be numerous. Promoting the development of fully integrated conservancies could also assist land reform. The economies of scale and centralized management in conservancies would remove key barriers for entry into wildlife-based land uses for emerging farmers. Conservancies could be structured as corporate entities to allow investment by emerging farmers, creating alternative avenues for achieving land reform that would allow for the retention of existing capital and capacity. Proactive efforts by commercial conservancies to facilitate the integration of black farmers may improve prospects of being granted a favourable legislative environment.

Failure to exploit export markets for venison The economic value of wildlife-based land uses has been limited by failure to exploit potential export markets for venison, because of inconsistent meat supplies, lack of facilities to store venison, a shortage of EU-approved abattoirs, and lack of awareness among target markets of the health qualities of venison (Gödde, 2008).

Similar constraints limit the value of wildlife ranching elsewhere in southern Africa and our recommendations have regional applicability. Wildlife is outcompeting livestock throughout semi-arid areas of southern Africa, despite policies favouring the latter. A more level legislative environment would allow the full potential of wildlife-based land uses to be harnessed and could generate significant economic, social and conservation benefits.

\section{Acknowledgements}

We thank TRAFFIC East/Southern Africa and Tom Milliken for instigating this project and the German Federal Ministry for Economic Cooperation and Development and African Wildlife Conservation Fund for funding, the Ministry of Environment and Tourism, Namibian Agricultural Union, Namibian Professional Hunters Association, Conservancies Association of Namibia, WWF-Namibia, Annetjie du Preez, Harrald Marggraff, Almut Kronsbein, Danica Shaw, Laurie Marker, Chris Weaver, Jon Barnes, Uapii Kazahe, Sakkie Van Der Merwe and Wilfried Pack and all the farmers interviewed.

\section{References}

Albertson, A. (2010) The Scott Wilson 'fencing impacts' report: ten years on. In A Review of the Environmental, Social and Economic Impacts of Game and Veterinary Fencing in Africa with Particular Reference to the GLTFCA and KAZA TFCA (eds K. Ferguson \& J. Hanks), pp. 58-73. University of Pretoria, Pretoria, South Africa. Barnes, J., Alberts, M. \& MacGregor, J. (2010) An Economic Valuation of the Impact of Climate Change on Agricultural and Natural Resource Land Uses in Namibia. Unpublished Paper for Environmental Economics Programme, International Institute of Environment and Development, London, UK.

BARNES, J. \& DE JAGER, J. (1996) Economic and financial incentives for wildlife use on private land in Namibia and the implications for policy. South African Journal of Wildlife Research, 26, 37-46. 
Barnes, J. \& Jones, B. (2009) Game ranching in Namibia. In Evolution and Innovation in Wildlife Conservation in Southern Africa (eds B. Child, H. Suich \& A. Spenceley), pp. 113-126 Earthscan, London, UK

Barnes, J., Lange, G., Nhuleipo, O., Muteyauli, P., Katoma, P., Amupolo, H. et al. (2009) Preliminary Valuation of the Wildlife Stocks in Namibia: Wildlife Asset Accounts. Ministry of Environment and Tourism Report, Windhoek, Namibia.

Barnett, R. \& Patterson, C. (2006) Sport Hunting in the Southern African Development Community (SADC) Region: An Overview. TRAFFIC East/Southern Africa, Johannesburg, South Africa.

Bond, I., Child, B., De la Harpe, D., Jones, B., Barnes, J. \& Anderson, H. (2004) Private-land contribution to conservation in South Africa. In Parks in Transition (ed. B. Child), pp. 29-62. Earthscan, London, UK.

Bothma, J. Du P. \& Du Toit, J.G. (2009) Game Ranch Management. Van Schaik, Pretoria, South Africa.

Bothma, J., Suich, H. \& Spenceley, A. (2009) Extensive wildlife production on private land in South Africa. In Evolution and Innovation in Wildlife Conservation in Southern Africa (eds B. Child, H. Such \& A. Spenceley), pp. 147-163. Earthscan, London, UK.

Carruthers, J. (2008) "Wilding the farm or farming the wild"? The evolution of scientific game ranching in South Africa from the 1960 s to the present. Transactions of the Royal Society of South Africa, 63, 160-181.

CHILD, B. (2000) Making wildlife pay: converting wildlife's comparative advantage into real incentives for having wildlife in African savannas. In Wildlife Conservation by Sustainable Use (eds H. Prins, J. Grootenhuis \& T. Dolan), pp. 335-388. Kluwer, Wageningen, The Netherlands.

Child, B. (2009) Private conservation in southern Africa: practice and emerging principles. In Evolution and Innovation in Wildlife Conservation in Southern Africa (eds B. Child, H. Suich \& A. Spencely), pp. 103-112. Earthscan, London, UK.

Child, G. \& Riney, T. (1987) Tsetse control hunting in Zimbabwe, 1919-1958. Zambezia, XIV, 11-71.

Cumming, D. (2004) Performance of parks in a century of change. In Parks in Transition (ed. B. Child), pp. 105-124. Earthscan, London, UK.

Cumming, D. (2010) Linkages, wildlife corridors and shortfalls in the KAZA TFCA. In A Review of the Environmental, Social and Economic Impacts of Game and Veterinary Fencing in Africa with Particular Reference to the GLTFCA and KAZA TFCA (eds K. Ferguson \& J. Hanks), pp. 119-125. University of Pretoria, Pretoria, South Africa.

Dasmann, R.F. \& Mossman, A.S. (1961) Commercial use of game animals on a Rhodesian ranch. Wildlife, 3, 7-14.

De KLerk, J.N. (2004) Bush Encroachment in Namibia. Ministry of Environment and Tourism, John Meinert Printing, Windhoek, Namibia.

Duffy, R. (200o) Killing for Conservation: Wildlife Policy in Zimbabwe. James Currey, Oxford, UK.

DU ToIT, R. (2004) Review of Wildlife Issues Associated with Land Reform in Zimbabwe. WWF-SARPO Occasional Paper, Number 10, Harare, Zimbabwe.

DVS (2007) Veterinary Science, Transboundary Animal Diseases and Markets. Unpublished Report. Namibian Ministry of Agriculture, Directorate of Veterinary Services, Windhoek, Namibia.

ERB, P. (2004) Consumptive wildlife utilization as a land use in Namibia. MBA thesis. University of Stellenbosch, Stellenbosch, South Africa.

Falkena, H. (2003) Game Ranch Profitability in South Africa. The SA Financial Sector Forum, Rivonia, South Africa.
Fryxell, J. \& Sinclair, A. (1988) Causes and consequences of migration by large herbivores. Trends in Ecology \& Evolution, 3, $237-241$.

Gibson, C. (1999) Politicians and Poachers: The Political Economy of Wildlife Policy in Africa. Cambridge University Press, Cambridge, UK.

Gödde, T. (2008) Analysis of the Namibian Game Meat Sector: Potentials and Constraints for the Supply of Exports Markets. Namibian Game Meat Task Team Report. Windhoek, Namibia.

Hayward, M., Henschel, P., O’Brien, J., Hofmeyr, M., Balme, G. \& Kerley, G. (2006) Prey preferences of the leopard. Journal of Zoology, 270, 298-313.

Humavindu, M. \& Barnes, J. (2003) Trophy hunting in the Namibian economy: an assessment. South African Journal of Wildlife Research, 33, 65-70.

Jansen, D., Bond, I. \& Child, B. (1992) Cattle, Wildlife, Both or Neither? WWF multispecies project, project paper number 27, Harare, Zimbabwe.

JMPIN (2000) JMPIN Version 4.o.2. SAS Institute, Cary, USA.

KRug, W. (2001) Private Supply of Protected Land in Southern Africa. World Bank/OECD International Workshop on Market Creation for Biodiversity Products and Services, Paris, France.

Lamprechts, M. (2009) Trophy Hunting in Namibia from the 1960 s to the Present Day. Namibian Professional Hunting Association Report, Windhoek, Namibia.

Langholz, G. \& Kerley, G. (2006) Combining Conservation and Development on Private Lands: An Assessment of Ecotourism-Based Private Game Reserves in the Eastern Cape. Nelson Mandela Metropolitan University Report, Port Elizabeth, South Africa.

Laubscher, J., Jooste, A., Mbai, S. \& Idsardi, E. (2007) Market Study for Goat Products and Venison. Meat Board of Namibia Report, Windhoek, Namibia.

LEAD (2005) Our Land We Farm: An Analysis of the Namibian Commercial Agricultural Land Reform Process. Land, Environment and Development Project Report. Legal Assistance Centre, Windhoek, Namibia.

Lindner, J. (2002) Handling nonresponse error in the Journal of International Agricultural Extension Education. Fall, 9, 55-60.

Lindsey, P.A., Romañach, S. \& Davies-Mostert, H. (2009) The importance of conservancies for enhancing the conservation value of game ranch land in southern Africa. Journal of Zoology, 277, 99-105.

Lindsey, P.A., Balme, G.A., Booth, V.A. \& Midlane, N. (2012) The significance of African lions for the financial viability of trophy hunting and the maintenance of wild land. PLoS ONE, 7(1), e29332.

MacKenzie, J.M. (1988) The Empire of Nature: Hunting, Conservation and British Imperialism. Manchester University Press, Manchester, UK.

Marker, L., Mills, M. \& Macdonald, M. (2003) Factors influencing perceptions of conflict and tolerance toward cheetahs on Namibian farmlands. Conservation Biology, 17, 1290-1298.

MARTIN, R. (2004) The influence of veterinary control fences on wild large mammals in Caprivi, Namibia. In Conservation and Development Interventions at the Wildife/Livestock Interface (ed. S. Osofsky), 27-40. IUCN, Gland, Switzerland.

Martin, R. (2008) Review of Safari Hunting in Botswana. Botswana Wildlife Management Association Report, Maun, Botswana.

McLaughlin, D. (2010) Botswana Beef Industry and EU Trade Policy. Unpublished Report, Gaborone, Botswana.

Mendelsohn, J. (2006) Farming Systems in Namibia. Namibian National Farmers Union, Windhoek, Namibia. 
Murombedzi, J. (2003) Pre-colonial and Colonial Conservation Practices in Southern Africa. IUCN Report. Http://dss.ucsd.edu/ _ccgibson/docs/Murombedzi\%20-\%2oPrecolonial\%20and\% 20Colonial\%20Origins.pdf [accessed December 2010].

NACSO (Namibian Association of CBNRM Support Organisations) (2010) Http://www.okacom.org/geonetwork/srv/ en/metadata.show.embedded?uuid=40a99379-a5d1-42e1-b71a$523 \mathrm{f} 876 \mathrm{f} 8995$ [accessed August 2010].

NAMC (2006) Report on the Investigation to Identify Problems for Sustainable Growth and Development in South African Wildlife Ranching. National Agricultural Marketing Council Report, Pretoria, South Africa.

Namibian Ministry of Works and Transport (2011) Namibia Rainfall Performance at Specified Places. Http://www.meteona.com/ climate/Monthly_Seasonal_Rainfall_Performance_ Monitoring_Bulletin.pdf [accessed May 2011].

NNF (2010) Namibia Nature Foundation. Http://www.nnf.org.na/ index.php [accessed June 2010].

Price-Waterhouse (1994) The Lowveld Conservancies: New Opportunities for Productive and Sustainable Land Use. PriceWaterhouse, Harare, Zimbabwe.

Scoones, I. \& Wolmer, W. (2008) Foot-and-Mouth Disease and Market Access: Challenges for the Beef Industry in Southern Africa. Working Paper 1, Institute for Development Studies, Brighton, UK.

Sims-Castley, R., Kerley, G., Geach, B. \& Langholz, J. (2005) Socio-economic significance of ecotourism-based private game reserves in South Africa's Eastern Cape Province. Parks, 15, 6-18.

TAYlor, R. \& MARTin, R. (1987) Effects of veterinary fences on wildlife conservation in Zimbabwe. Environmental Management, 11, $327-334$.
Thomson, G. (2008) Regional Positions on Foot-and-Mouth Disease Control in Southern Africa. Unpublished Report. Institute of Development Studies, Brighton, UK.

WTTC (World Travel and Tourism Council) (2012) Travel and Tourism Economic Impact, 2012: Namibia. Http://www.wttc.org/ site_media/uploads/downloads/namibia2012.pdf [accessed June 2012].

\section{Appendix}

The appendix for this article is available online at http:// journals.cambridge.org

\section{Biographical sketches}

Peter Lindey works throughout Southern Africa on wildlife-based land uses, the bushmeat trade and predator conservation. CARL HAVEMANN is studying the roan antelope in Botswana. ROBIN LINES has undertaken applied research on large carnivore conservation in Southern Africa since 2002. A ARON PRICE works on livestock water quality compliance. TARRYN RETIEF is studying the effects of biological gradients on biodiversity in Botswana. TIEMEN RHEBERGEN works as a consultant in geographical information systems and agriculture. CORNELIS VAN DER WAAL's research interests include applied rangeland ecology in savannah and desert systems, and mine restoration. Stephanie S. Romañach investigates wildlife responses to climate change and ecosystem restoration in the Everglades. She has worked widely in Southern and Eastern Africa and helps run the African Wildlife Conservation Fund. 